\title{
Stably Transfected Common Fragile Site Sequences Exhibit Instability at Ectopic Sites
}

\author{
Ryan L. Ragland, Michael W. Glynn, Martin F. Arlt, Thomas W. Glover* \\ Department of Human Genetics, University of Michigan, Ann Arbor, MI
}

Common fragile sites (CFSs) are loci that are especially prone to forming gaps and breaks on metaphase chromosomes under conditions of replication stress. Although much has been learned about the cellular responses to gaps and breaks at CFSs, less is known about what makes these sites inherently unstable. CFS sequences are highly conserved in mammalian evolution and contain a number of sequence motifs that are hypothesized to contribute to their instability. To examine the role of CFS sequences in chromosome breakage, we stably transfected two BACs containing FRA3B sequences and two nonCFS control BACs containing similar sequence content into HCTII 6 cells and isolated cell clones with BACs integrated at ectopic sites. Integrated BACs were present at just a few to several hundred contiguous copies. Cell clones containing integrated FRA3B BACs showed a significant, three to sevenfold increase in aphidicolin-induced gaps and breaks at the integration site as compared to control BACs. Furthermore, many FRA3B integration sites displayed additional chromosome rearrangements associated with CFS instability. Clones were examined for replication timing and it was found that the integrated FRA3B sequences were not dependent on late replication for their fragility. This is the first direct evidence in human cells that introduction of CFS sequences into ectopic nonfragile loci is sufficient to recapitulate the instability found at CFSs. These data support the hypothesis that sequences at CFSs are inherently unstable, and are a major factor in the formation of replication stress induced gaps and breaks at CFSs. (1) 2008 Wiley-Liss, Inc.

\section{INTRODUCTION}

Common fragile sites (CFSs) are chromosomal loci that are especially prone to forming cytogenetically visible gaps and breaks on metaphase chromosomes under conditions of replication stress such as treatment with low concentrations of the DNA polymerase inhibitor aphidicolin (APH) (reviewed in (Durkin and Glover, 2007)). These sites span several hundred kilobases to over a megabase in size with gaps and breaks occurring throughout the region and many are located within or span large genes. In addition to cytogenetically identifiable gaps and breaks, CFSs exhibit a number of other characteristics of unstable DNA in cultured cells including gross chromosome deletions (Wang et al., 1993), smaller submicroscopic deletions (Durkin et al., 2008), translocations (Glover and Stein, 1988), intrachromosomal gene amplifications (Coquelle et al., 1997), and sister chromatid exchanges (Glover and Stein, 1987). In cells pretreated with APH, CFSs are also preferred sites for the integration of transfected DNA (Rassool et al., 1991). Despite their instability, CFSs are found in all individuals and are a normal component of the human genome. Furthermore, CFSs are conserved in mammalian evolution (Soulie and De Grouchy, 1981; Elder and Robinson, 1989; Smeets and van de Klundert, 1990; Stone et al., 1991; McAllister and Greenbaum, 1997; Glover et al., 1998; RuizHerrera et al., 2004) and counterparts exist in yeast (Roeder and Fink, 1980; Dunham et al., 2002; Lemoine et al., 2005).

Although CFSs are normally stable in somatic cells in vivo, these sites are frequently rearranged in many cancer cell lines (Arlt et al., 2002; Huebner and Croce, 2003; Finnis et al., 2005). For example, the two most frequently expressed CFSs, FRA3B, and FRA16D are associated with the large tumor suppressor genes fragile histidine triad (FHIT) and WW domain-containing oxidoreductase (WWOX) respectively (Boldog et al., 1994; Wilke et al., 1994; Ohta et al., 1996; Ried et al., 2000; Bednarek et al., 2001). Heterozygous or homozygous deletion of these tumor suppressors is found early in tumorigenesis and is associated with a number of differ-

Additional Supporting Information may be found in the online version of this article.

Supported by: National Institutes of Health Grant; Grant number: CA43222.

*Correspondence to: Thomas W. Glover, Department of Human Genetics 4909 Buhl, Box 5618, 1241 East Catherine Street, University of Michigan, Ann Arbor, Michigan 48109-0618, USA.

E-mail: glover@umich.edu

Received 5 May 2008; Accepted 4 June 2008

DOI 10.1002/gcc.20591

Published online 9 July 2008 in

Wiley InterScience (www.interscience.wiley.com). 
ent cancers (Ohta et al., 1996; Michael et al., 1997; Huebner and Croce, 2003; Bartkova et al., 2005; Gorgoulis et al., 2005). It was recently shown that cells treated with APH form tumor-like deletions at a high frequency at FRA3B, supporting the hypothesis that such deletions are a result of replication stress (Durkin et al., 2008).

In recent years, a number of genes involved in the intra-S and G2/M checkpoints have been found to be important in maintaining the stability of CFSs, including ATR, BRCA1, CHK1, FANCD2, HUS1, and SMC1 (Casper et al., 2002; Arlt et al., 2004; Howlett et al., 2005; Musio et al., 2005; Durkin et al., 2006; Zhu and Weiss, 2007). In addition, several genes (RAD51, DNA-PKcs, and LIG4) that are involved in both homologous recombination and nonhomologous end joining DNA repair pathways have also been reported to be involved in the maintenance of CFSs stability (Schwartz et al., 2005). The importance of the ATR pathway in the maintenance of CFSs implicates stalled replication forks as having a central role in the instability of these sites. Although these studies have provided a basic understanding of the DNA damage response pathways involved in the maintenance of CFS instability, little is understood about what makes CFSs exceptionally susceptible to DNA damage.

There are a number of factors that could contribute to CFS instability. Primary among these is sequence. Although it is possible that a single sequence motif is responsible for the instability seen at CFSs, none of the cloned CFSs contain expanded di or trinucleotide repeats like those that are responsible for the instability seen at rare fragile sites (reviewed in (Sutherland, 2003)). In addition, gaps and breaks can occur throughout the large CFS regions, suggesting that if sequence contributes to instability it would most likely result from one or more motifs that are present throughout the entire CFS region. One sequence motif that is in accordance with this hypothesis is the flexibility peak. Flexibility peaks are defined as sequences that have a high local variation in DNA twist angle as measured using the TwistFlex program (Mishmar et al., 1998). Many CFSs contain a high number of flexibility peaks and it has been suggested that the formation of abnormal DNA structures at these sites during replication could be a causal factor in their instability (Boldog et al., 1997; Mishmar et al., 1998; Arlt et al., 2002; Mirkin and Mirkin, 2007). In support of this hypothesis, it has recently been shown that in yeast, an AT-rich sequence containing variable stretches of perfect AT repeats taken from a flexibility peak found in the human FRA16D CFS can cause fork stalling and chromosome breakage (Zhang and Freudenreich, 2007). It has also been suggested that other sequence motifs such as high repetitive element content may contribute to the instability of CFSs (Rozier et al., 2004). Finally, because CFSs are some of the latest sites in the genome to complete replication with some sites remaining unreplicated into the G2 phase of the cell cycle, late replication timing may also be causal to the instability of CFSs (Le Beau et al., 1998; Hellman et al., 2000; Palakodeti et al., 2004).

In experiments designed to determine the contribution of sequence to CFS instability, we addressed the question of whether the integration of BAC clones containing sequences from FRA3B are sufficient to recapitulate CFS-like instability at a novel genomic location. We found that cell clones containing either of two adjacent FRA3B BACs integrated at unique nonfragile site loci retained CFS-like instability at the ectopic sites. In addition, we found that the fragility of integrated CFS sequences was not dependent on late replication.

\section{MATERIALS AND METHODS}

\section{Identification and Retrofitting of BACs}

The Research Genetics (Huntsville, Alabama.) human genomic BAC library was screened using PCR probes for BAC clones containing sequence from intron 4 , exon 5 , and intron 5 of FHIT. PCR primers were designed using sequences obtained from the UCSC Genome Browser. E. coli containing the BACs were inoculated into $1 \mathrm{~L} \mathrm{LB}$ media containing $25 \mu \mathrm{g} / \mathrm{ml}$ chloramphenicol and incubated overnight at $37^{\circ} \mathrm{C}$. The pRetroES plasmid was used for retrofitting the BACs to contain neomycin resistance gene following the procedures outlined by Wang et al. (2001). Lysis and extraction of the BAC was done following the standard CsCl extraction protocols (Wilson, 2001). PFGE analysis was performed on extracted BACs digested with NotI to determine if correct retrofitting had occurred. To determine the exact sequence content of the genomic inserts end sequencing was preformed using T7 and SP6 primers flanking the genomic insert in the BAC.

\section{Sequence Analysis}

Flexibility peaks were defined and determined using the TwistFlex program (http://margalit.huji. ac.il/TwistFlex/Home.html), which analyzes DNA flexibility at the twist angle. Repetitive element 
content (SINEs, LINEs, LTR elements, and DNA elements) was measured and defined using the repeat masker program (http://www.repeatmasker. org). Additionally, the online programs Palindrome (http://bioweb.pasteur.fr/seqanal/interfaces/palindrome. html), Inverted Repeat Finder (Warburton et al., 2004), and Tandem Repeat Finder (Benson, 1999) were used for examination of BAC sequence. Default settings for all values for all programs were used.

\section{Transfection}

HCT116 cells were transfected using the DOTAP liposomal transfection reagent (Roche Applied Science). A $10 \mathrm{~cm}^{2}$ cell culture plate was seeded with $1.5 \times 10^{6}$ cells and incubated overnight at $37^{\circ} \mathrm{C}$. Ten micrograms of supercoiled BAC DNA was subsequently transfected into these cells following the manufacturer's protocols. The medium was replaced after $10 \mathrm{hr}$ of incubation with selective medium containing $500 \mu \mathrm{g} / \mathrm{ml}$ of active G418 (Gibco). Stable G418 resistant clones were cloned and analyzed for integration of the BAC by real time PCR and fluorescent in situ hybridization.

\section{Cell Culture and Fragile Site Analysis}

HCT116 cells were grown in Dulbecco's modified essential medium containing $10 \%$ fetal bovine serum, L-glutamine, and penicillin/streptomycin at $37^{\circ} \mathrm{C}$ and $5 \% \mathrm{CO}_{2}$. Cells resistant for $\mathrm{G} 418$ were grown as above with medium supplemented with $500 \mu \mathrm{g} / \mathrm{ml} \mathrm{G} 418$.

Cells were treated with $0.4 \mu \mathrm{M}$ APH for $24 \mathrm{hr}$ before metaphase chromosome harvest to induce fragile site expression. Metaphases were harvested by treating the cells with $50 \mathrm{ng} / \mathrm{ml}$ colcemid for 45 min. Cells were then placed in $0.075 \mathrm{M} \mathrm{KCl}$ at $37^{\circ} \mathrm{C}$ for $18 \mathrm{~min}$ and fixed in Carnoy fixative $(3: 1$ methanol:glacial acetic acid) for $2 \mathrm{hr}$ before replacing the fixative several times. Fixed cells were dropped on slides and aged at room temperature for $48 \mathrm{hr}$ before FISH analysis.

Fifty metaphases from each cell clone were scored for total chromosome gaps and breaks as well as gaps and breaks at the sites of FISH probe hybridization. To account for the differences in treatment from one sample to another, gaps and breaks at the sites of FISH probe hybridization were normalized using total gaps and breaks per cell.

\section{FISH}

The BACs used for transfection were used for FISH analysis of the clones containing those BACs. Established FISH protocols were followed (Wilke et al., 1996). Probes were labeled with biotin 14-dATP using the BioNic translation kit (Invitrogen, Carlsbad, CA). Bound probe was detected using fluorescein isothiocynate conjugated avidinDCS (Vector Laboratories, Burlingame, CA) followed by fluorescein conjugated anti-avidin IgG (IgG). Chromosomes were stained using 4',6-diamidino-2-phenylindole (DAPI; Vector Laboratories, Burlingame, CA). Fluorescent signals were detected using a Zeiss Axioscope epifluorescence microscope.

\section{Reduction of Copy Number}

To reduce the copy number of the BACs at the sites of integration, cells were treated with a retrovirus, AdCre1, expressing Cre recombinase (Dr. Frank Graham McMaster University, Hamilton, Ontario, Canada). One well of a six well plate was seeded with $8 \times 10^{4}$ cells. Cells were allowed to settle overnight and then treated with the retrovirus. Cells were allowed to recover for $48 \mathrm{hr}$ and treated with retrovirus again as earlier. After the 48 hr of recovery, cells were plated out at $\sim 200$ cells/ $10 \mathrm{~cm}^{2}$ for the isolation of cell clones.

\section{Quantitative Real Time PCR}

Copy number of transfected BACs was estimated by genomic real time PCR using the SYBR green assay and the iCycler system (BIO RAD). Genomic DNA was extracted by standard alkaline lysis, and about $50 \mathrm{ng}$ of total genomic DNA was used per PCR reaction. Primers were designed using primer 3 (http://frodo.wi.mit.edu/cgi-bin/ primer3/primer3_www.cgi). All primer pairs were optimized using a standard curve of $200 \mathrm{ng}, 20 \mathrm{ng}$, $2 \mathrm{ng}$, and $0 \mathrm{ng}$ samples of normal HCT116 and/or LD055 genomic DNA. Experimental samples were run in triplicate over two separate experiments for a total of six replicates for each primer pair and eighteen replicates for each clone. A GAPDH primer pair was run for each sample in triplicate over two experiments to determine total DNA input for each sample. All results were analyzed for copy number using the $2^{-\Delta \Delta \text { ct }}$ method (Livak and Schmittgen, 2001). 
A.

FRA3B $\sim 1 \mathrm{Mb}$

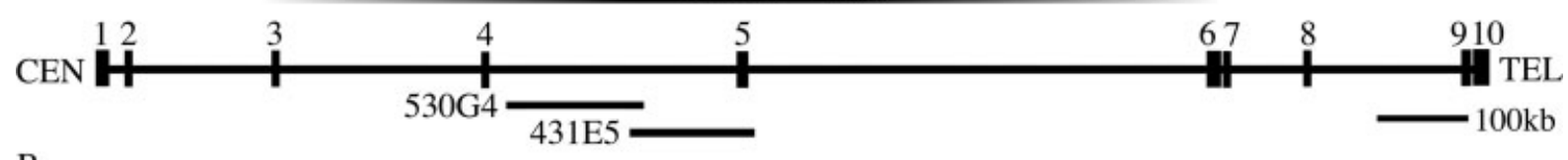

B.

Chr3p14.2: FRA3B BAC 530G4 (150.7kb)

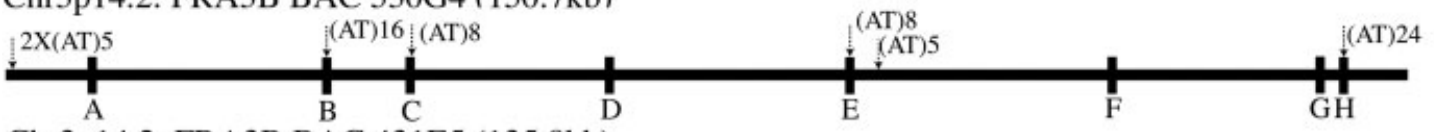

Chr3p14.2: FRA3B BAC 431E5 (135.8kb)

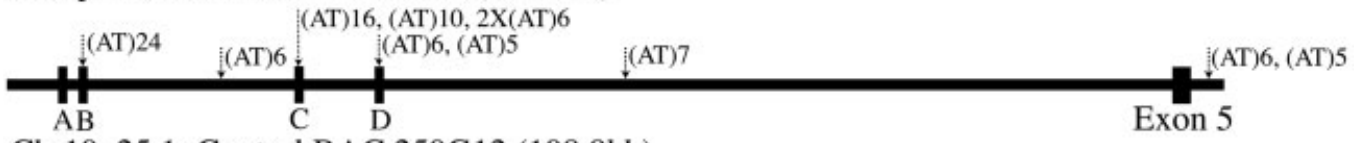

Chr10q25.1: Control BAC 250G12 (109.9kb)

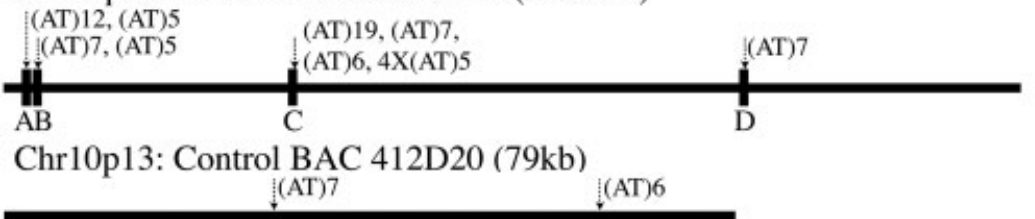

No Flexibility Peaks Found

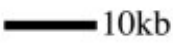

Figure I. (A) Physical map of the FHIT gene and FRA3B locus. The position and size of the two FRA3B BACs (43IE5 and 530G4) is indicated. (B) Physical map of all four BAC genomic inserts. The size and genomic location of the inserts is indicated. The number and location of flexibility peaks are indicated as letters for each BAC. The location and size of perfect AT repeated greater than $(A T)_{4}$ is also indicated.

\section{RESULTS}

\section{Characterization and Retrofitting of CFS and Control BACs}

Two BAC clones, 431E5 and 530G4, containing genomic inserts within the FHIT gene were chosen for these experiments. These two BACs are located in the center of fragility of the most frequently expressed CFS, FRA3B, and overlap by $14.5 \mathrm{~kb}$ (Fig. 1). FRA3B BAC $431 \mathrm{E} 5$ is $135.8 \mathrm{~kb}$ in length, has $62 \%$ AT content, $45 \%$ repetitive element content, contains four flexibility peaks, and 11 perfect AT repeats greater than or equal to $(\mathrm{AT})_{5}$ in size (Table 1). The FRA3B BAC 530G4 is $150.7 \mathrm{~kb}$ in size, has $62 \%$ AT content, $39 \%$ repetitive element content, contains eight flexibility peaks, and seven perfect AT repeats greater than or equal to $(\mathrm{AT})_{5}$ in size.

Two control BACs taken from regions not containing CFSs were chosen to match the sequence content of the FRA3B BACs. Control BAC 250 G12 is located at $10 \mathrm{q} 25.1$, which does not contain any known genes, is $109.9 \mathrm{~kb}$ in size, has $62 \%$ AT content, $48 \%$ repetitive element content, contains four flexibility peaks, and has 12 perfect AT repeats greater than or equal to $(A T)_{5}$. Control BAC 412 D20 is located in intron 2 of the large gene, FERM domain-containing protein $4 \mathrm{~A}(F R M D 4 A)$ at $10 \mathrm{p} 13$, is
$79 \mathrm{~kb}$ in size, has $56 \%$ AT content, $39 \%$ repetitive element content, but contains no flexibility peaks and only two perfect AT repeats greater than or equal to $(\mathrm{AT})_{5}$ in size. All four BACs were examined for the additional sequence motifs of inverted repeats, palindromes, and tandem repeats all of which are capable of forming strong secondary structures. Both FRA3B and control BACs contain a similar number of tandem repeats and palindromes (Table 1). However, control BAC 412D20 contains four times the number of inverted repeats as the experimental BACs, whereas control BAC 250G12 has only half the number of inverted repeats.

All BACs were retrofitted to be resistant to geneticin (G418) using the pRetroES plasmid as described by Kim et al., (1998) (Supplemental Fig. 1). The size, integrity, and sequence content of the genomic inserts for all BACs was confirmed by end sequencing and pulsed field gel electrophoresis (Supplemental Fig. 2).

The two FRA3B BACs and two control BACs were stably transfected into HCT116 cells and clones were selected using G418 resistance. Four cell clones containing an integration of the FRA3B BAC 431E5, two cell clones containing the FRA3B BAC 530G4, four cell clones containing the control BAC 412D20, and two cell clones containing the control BAC 250G12 were identified (Fig. 2). Each 
TABLE I. Location and Sequence Content of the Genomic Inserts of the BACs

\begin{tabular}{|c|c|c|c|c|}
\hline BAC & 43IE5 & $530 \mathrm{G} 4$ & $4 \mid 2 \mathrm{D} 20$ & $250 \mathrm{G} / 2$ \\
\hline Type & FRA3B & FRA3B & Control & Control \\
\hline Chr. & $3 p \mid 4.2$ & $3 p \mid 4.2$ & $10 p \mid 3$ & $10 q 25$ \\
\hline Size (kb) & 135.8 & 150.7 & 79 & 109.9 \\
\hline AT $(\%)$ & 61.99 & 62.10 & 56.07 & 62.23 \\
\hline Repeat Element ${ }^{\mathrm{a}}(\%)$ & 44.83 & 38.96 & 39.36 & 48.16 \\
\hline SINE (\%) & 9.88 & 9.84 & 19.57 & 6.84 \\
\hline LINE (\%) & 24.42 & 11.37 & 7.90 & 22.95 \\
\hline Flex Peaks (/l00 kb) & 2.95 & 5.31 & 0.00 & 3.64 \\
\hline Inverted Repeats (//00 kb) & 102.36 & 104.18 & 432.91 & 42.77 \\
\hline Palin. ${ }^{\mathrm{b}}(/ 100 \mathrm{~kb})$ & 117.08 & 69.01 & 67.09 & 131.94 \\
\hline Tandem Repeats (/100 kb) & 15.46 & 21.90 & 50.63 & 26.39 \\
\hline$(\mathrm{AT})_{\geq 5}(/ / 00 \mathrm{~kb})$ & 8.10 & 4.64 & 2.53 & 10.92 \\
\hline
\end{tabular}

${ }^{\text {a }}$ Percent of sequence that is repetitive elements.

${ }^{\mathrm{b}}$ Number of palindromes/100 kb of sequence.

A

FRA3B BAC 431E5

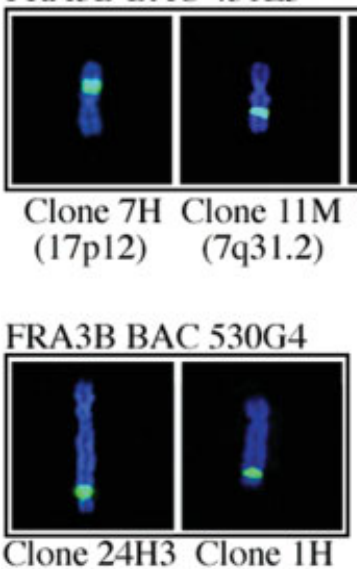

$(2 \mathrm{q} 35) \quad(4 \mathrm{q} 32)$

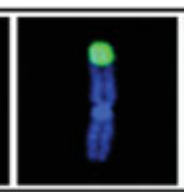

Clone $4 \mathrm{M}$

(1p36)

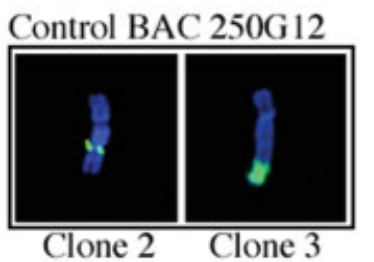

(12q20)

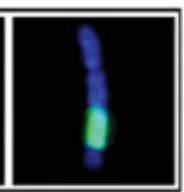

Clone $8 \mathrm{~L}$

(2q23)

\section{(6q)}

Control BAC 412D20

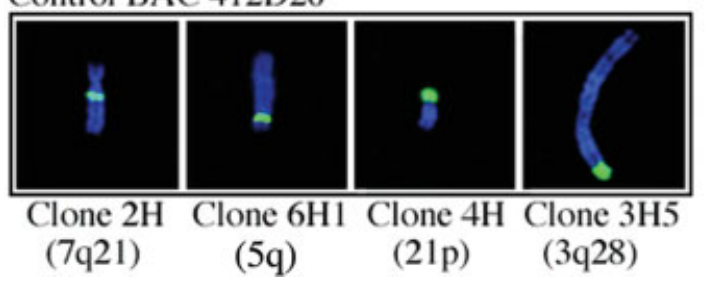

B

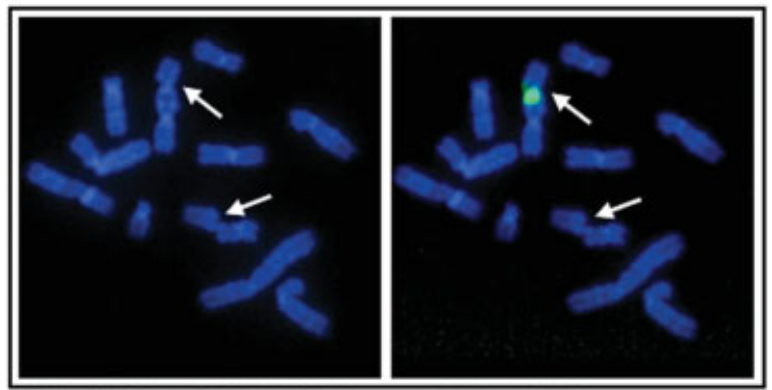

FRA3B BAC 431E5 Clone 11M +APH

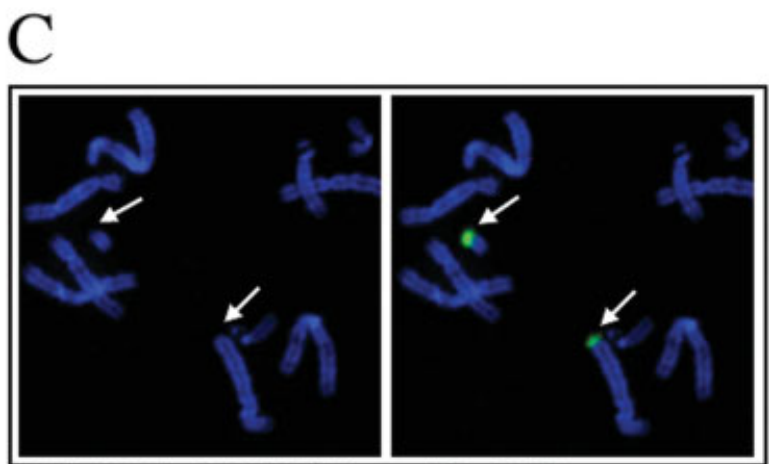

FRA3B BAC 530G4 Clone 1H +APH

Figure 2. (A) Representative FISH signals showing the relative size and genomic location of the BAC insertions. ( $B$ and $C$ ) Two partial metaphase spreads demonstrating both a typical CFS-like break and a complete chromosome break respectively, as indicated by the arrows, at the sites of integration. [Color figure can be viewed in the online issue, which is available at www.interscience.wiley.com.]

clonal cell population contained a single, unique integration site and all integration sites were cytogenetically distinct from any cloned CFSs.

\section{Integrated FRA3B BACs are More Fragile Than Control BACs}

To determine if the integrated BACs retained characteristics of CFSs, we scored total gaps and breaks on metaphase chromosomes, gaps and breaks specifically at the sites of integration, and at the endogenous FRA3B loci using FISH with labeled BAC DNA as probe. In the absence of APH, no clone showed a significant number of gaps and breaks at the integration site $(P$ value range 0.118 1) (Fig. 3a) or at the endogenous FRA3B loci (data not shown). Following the treatment with $0.4 \mu \mathrm{M}$ 
A
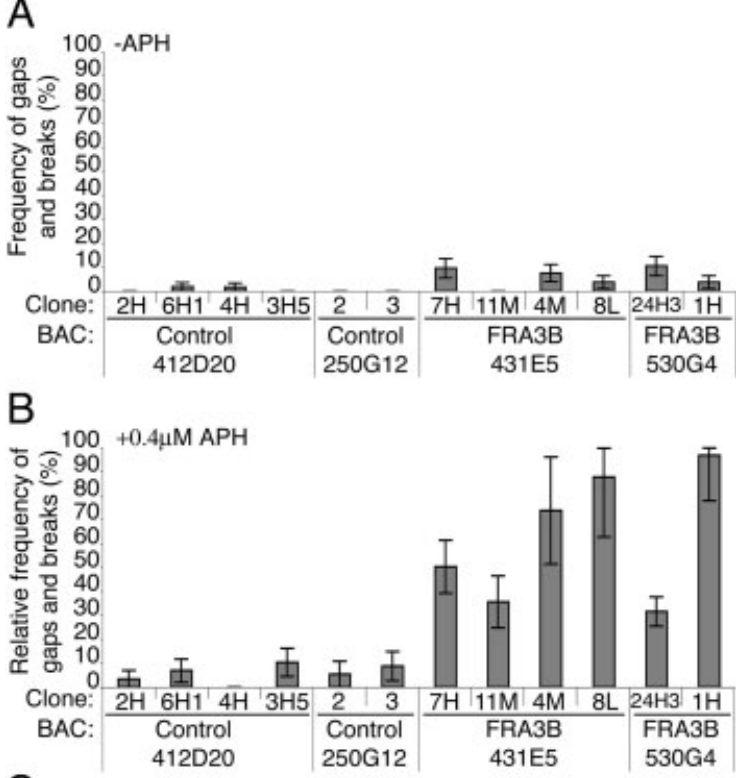

C

$100+0.44 \mathrm{M} \mathrm{APH}$

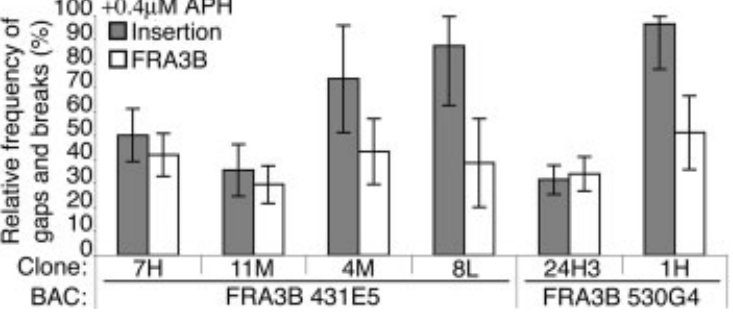

Figure 3. Cells containing FRA3B BAC insertions show elevated gaps and breaks at the integration site when treated with $0.4 \mu \mathrm{m} \mathrm{APH}$. All APH treated samples were normalized using total gaps and breaks as a measure. (A) Percent of integration sites with gaps or breaks in all untreated clones as seen in 50 metaphases for each clone. (B) The relative percentage of gaps and breaks at the site of integration after treatment with $0.4 \mu \mathrm{m} \mathrm{APH}$. (C) Relative percentage of gaps and breaks at both the integration site and the endogenous FRA3B locus for each clone.

$\mathrm{APH}$, all six cell clones with integrated control BACs showed a low frequency $(0-11 \%)$ of breakage at the integration site. This level of breakage is not significantly different from untreated cells $(P$ value range 0.49-1). However, cell clones containing integrated FRA3B BACs showed a statistically significant three to ninefold increase in gaps and breaks at the integration site as compared to untreated clones, and a three to sevenfold increase in gaps and breaks at the integration site when compared with the APH treated control cell clones ( $P$ value range $0.023-<0.00001$ ) (Fig. $3 b$ ). In addition, cell clones containing integrated FRA3B BACs showed a similar, or slightly higher, level of breakage at the ectopic integration site as compared to the endogenous FRA3B loci following 0.4 $\mu \mathrm{M}$ APH treatment (Fig. 3c). Because both FRA3B BACs were equally unstable, these results suggest that both BACs contain sequences capable of transferring the instability seen at the FRA3B locus to ectopic sites in the genome.

\section{Integrated FRA3B BACs Promote Chromosomal Rearrangements}

In addition to increased gaps and breaks on metaphase chromosomes, eight of the twelve cell clones containing integrated BACs displayed a variety of chromosome rearrangements at the sites of integration (Fig. 4). Cell clones containing FRA3B BACs had a significantly $(P<0.0001)$ higher frequency of these rearrangements as compared to clones containing control BACs, $11.3 \%$ (72/638 metaphases) and 4.3\% (27/630 metaphases), respectively (Table 2). These include dicentric chromosomes, ring chromosomes, laddered amplicons, and massive amplification (Fig. 4 and Table 2). In addition, the FRA3B BAC $530 \mathrm{G} 4$ cell clone $24 \mathrm{H} 3$ showed a total of eight metaphases with FISH signals exclusively on fragmented extrachromosomal elements, and a number of interphase nuclei with micronuclei or chromatin bridge formations (Fig. 4g,j, and k). The FRA3B BAC $431 \mathrm{E} 5$ cell clone $4 \mathrm{M}$ contained one metaphase showing a fusion of the sister chromatids at the integration site (Fig. 4e). The amplifications, laddered FISH signal, sister chromatid fusion, and nuclear chromatin bridges are all consistent with breakage fusion bridge cycle (BFBC) events, which have previously been found to be associated with CFSs (Kuo et al., 1994; Coquelle et al., 1997, 2002).

The most striking example of this was found in the FRA3B BAC cell clone 24H3, which demonstrated multiple chromosomal rearrangements indicative of an ongoing repair process occurring at the integration site. In this series of metaphases, a normal signal becomes amplified, most likely through BFBC, and forms multiple breaks that eventually create extra chromosomal elements (Fig. 4f-4i). These extra chromosomal elements are then shuttled into micronuclei for removal from the cell (Fig. 4j-4k). Three of the six FRA3B BAC cell clones displayed such amplifications with multiple breaks indicating that this process is not limited to the one clone described here.

In total, four of the six cell clones containing FRA3B BAC integrations displayed metaphases with rearrangements at the site of integration, and the majority ( $47 / 74$ or $63.5 \%)$ of these rearrangements were of the types associated with the BFBC. Three of the six control BAC containing cell clones also had metaphases with rearrange- 

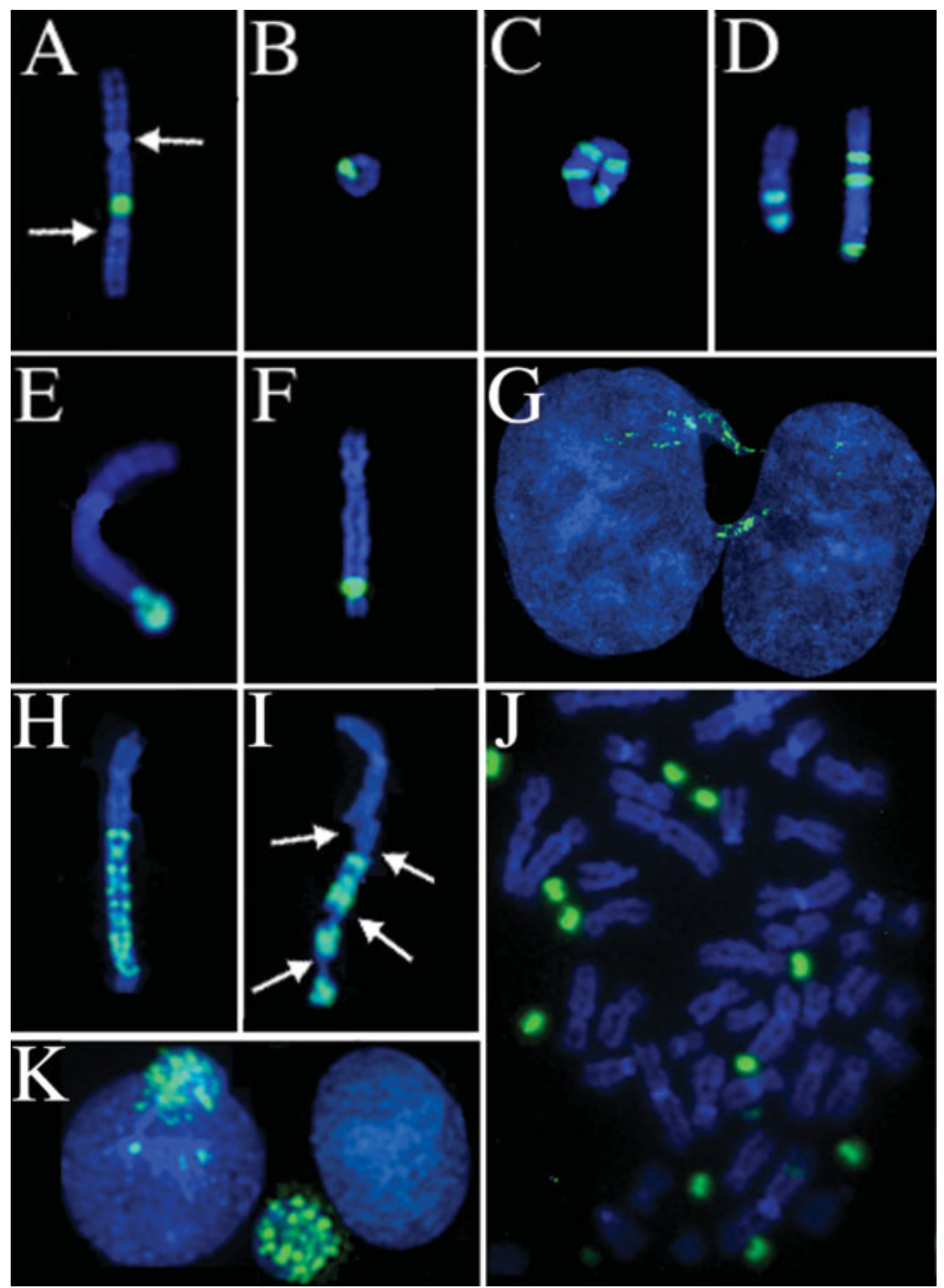

Figure 4. Chromosomal rearrangements at the sites of BAC integrations as seen on metaphase chromosomes. The FISH signal indicates integrated BAC sequence. (A) Dicentric chromosome observed in FRA3B BAC clone 43IE5 4M. The arrows indicate the two centromeres. (B) Ring chromosome in control BAC clone 4I2D20 6HI. (C) Ring chromosome containing multiple FISH signals in the FRA3B BAC clone 530G4 24H3. (D) Multiple FISH signals due to amplification in the FRA3B BAC clone 530G4 24H3. (E) Chromosome containing fused sister chromatids observed in the FRA3B BAC clone 43IE5 4M. (F-K) Clonal evolution of aberrations seen in the FRA3B BAC clone 530G4 24H3. (F) The FISH signal seen in the majority of cells from this clone. (G) A bridge containing multiple FISH signals as seen between two interphase nuclei. $(\mathrm{H})$ A large amplification of the integrated BAC. The laddering seen is indicative of multiple rounds of BFBC. (I) An example of multiple breaks seen in the amplified region. (J) Extrachromosomal fragments presumably originating from unstable amplified integrated BAC. (K) Micronuclei containing FISH signals from multiple fragmented chromosomal elements. ments at the integration site. However, compared to the cell clones containing FRA3B BAC integrations, the control cell clones exhibited very few rearrangements of the type associated with $\mathrm{BFBC}$ events $(3 / 27$ or $11.1 \%)$, suggesting that the mechanisms involved in forming the rearrangements in the FRA3B clones are different than those in the control clones.

\section{The BACs Integrated in Multiple Copies}

It was apparent from the size and intensity of the FISH signals that all of the cell clones contained multiple copies of the integrated BACs, presumably resulting either from integration of concatamers or amplification following integration. To determine the BAC copy number at the integration site and to clarify whether the BACs integrated as whole units or as fragments, we performed quantitative real time PCR (Q-PCR) analysis of genomic DNA from each clone. This analysis was performed using three PCR markers for each clone, one at either end of the genomic insert in the BAC and one in the center.

The copy number of the integrated BACs varied from $\sim 3$ copies to over 300 copies (Table 3). For most of the cell clones the Q-PCR values for all three markers were not significantly different, indicating that integrated BACs were present as whole units. Although all clones contained sequence corresponding to all three markers, the FRA3B BAC 
TABLE 2. Type and Number of Abnormal Signals Seen in Each Clone at the Integration Site

\begin{tabular}{|c|c|c|c|c|c|c|c|c|c|c|c|c|c|c|c|c|c|}
\hline \multirow[b]{2}{*}{ BAC } & \multirow[b]{2}{*}{ Clone } & \multicolumn{2}{|c|}{$\begin{array}{c}\text { Dicentric } \\
\text { Chr. }^{a} \\
\text { APH }\end{array}$} & \multicolumn{2}{|c|}{$\begin{array}{l}\text { Ring } \\
\text { Chr. } \\
\text { APH }\end{array}$} & \multicolumn{2}{|c|}{$\begin{array}{l}\text { Ring } \\
\text { Chr. } \\
\text { Multi. } \\
\text { APH }\end{array}$} & \multicolumn{2}{|c|}{$\begin{array}{l}\text { Multi. } \\
\text { Chr. }^{\text {d }} \\
\text { APH }\end{array}$} & \multicolumn{2}{|c|}{$\begin{array}{c}\text { Large } \\
\text { Amp. } \\
\text { APH }\end{array}$} & \multicolumn{2}{|c|}{$\begin{array}{c}\text { Chr. Ele. } \\
\text { APH }\end{array}$} & \multicolumn{2}{|c|}{$\begin{array}{l}\text { Fused } \\
\mathrm{Chr}^{g} \\
\text { APH }\end{array}$} & \multicolumn{2}{|c|}{$\begin{array}{l}\text { Total } \\
\text { APH }\end{array}$} \\
\hline & & - & + & - & + & - & + & - & + & - & + & - & + & - & + & - & + \\
\hline Control & $2 \mathrm{H}$ & 0 & 0 & 0 & 0 & 0 & 0 & 0 & 0 & 0 & 0 & 0 & 0 & 0 & 0 & 0 & 0 \\
\hline \multirow[t]{3}{*}{$4 I 2 D 20-R$} & $6 \mathrm{HI}$ & 2 & I & 5 & 4 & 0 & I & 0 & I & 0 & 0 & 0 & 0 & 0 & 0 & 7 & 7 \\
\hline & $4 \mathrm{H}$ & 2 & 6 & 0 & 0 & 0 & 0 & 0 & 0 & 1 & I & 0 & 0 & 0 & 0 & 3 & 7 \\
\hline & $3 \mathrm{H} 5$ & I & 2 & 0 & 0 & 0 & 0 & 0 & 0 & 0 & 0 & 0 & 0 & 0 & 0 & 1 & 2 \\
\hline Control & 2 & 0 & 0 & 0 & 0 & 0 & 0 & 0 & 0 & 0 & 0 & 0 & 0 & 0 & 0 & 0 & 0 \\
\hline $250 \mathrm{GI} 2$ & 3 & 0 & 0 & 0 & 0 & 0 & 0 & 0 & 0 & 0 & 0 & 0 & 0 & 0 & 0 & 0 & 0 \\
\hline FRA3B & $7 \mathrm{H}$ & 3 & I & 0 & 0 & 0 & 0 & 0 & I & 2 & 11 & 0 & 0 & 0 & 0 & 5 & 13 \\
\hline \multirow[t]{3}{*}{43 IE5 } & IIM & 0 & 0 & 0 & 0 & 0 & 0 & 0 & 0 & 0 & 0 & 0 & 0 & 0 & 0 & 0 & 0 \\
\hline & $4 M$ & 2 & 3 & 0 & 0 & 0 & 0 & I & 0 & 0 & 6 & 0 & 0 & 0 & I & 3 & 10 \\
\hline & $8 \mathrm{~L}$ & 0 & 0 & 0 & 0 & 0 & 0 & 0 & I & 0 & I & 0 & 0 & 0 & 0 & 0 & 2 \\
\hline FRA3B & $24 \mathrm{H} 3$ & 4 & 7 & 0 & 0 & 0 & 3 & 3 & 3 & 3 & 6 & 4 & 4 & 0 & 0 & 14 & 23 \\
\hline $530 \mathrm{G} 4$ & $\mathrm{IH}$ & 2 & 2 & 0 & 0 & 0 & 0 & 0 & 0 & 0 & 0 & 0 & 0 & 0 & 0 & 2 & 2 \\
\hline Total & & 16 & 22 & 5 & 4 & 0 & 4 & 4 & 6 & 6 & 25 & 4 & 4 & 0 & I & 35 & 66 \\
\hline
\end{tabular}

Number of metaphases containing:

${ }^{a}$ FISH signal on a dicentric chromosome.

${ }^{b} \mathrm{FISH}$ signal on a ring chromosome.

'More than one FISH signal on a ring chromosome.

'More than one FISH signal on a single chromosome.

eVery large amplifications of FISH signal on a single chromosome.

${ }^{f}$ Extra chromosomal elements marked by FISH signal.

${ }^{\mathrm{g}} \mathrm{FISH}$ signal at fused sister chromatids.

TABLE 3. Copy Number Analysis for All PCR Markers Across All BAC Clones

\begin{tabular}{llcccr}
\hline BAC & Clone & PCR I & PCR 2 & PCR 3 & Avg \\
\hline Control & $2 \mathrm{H}$ & $12 \pm 3$ & $22 \pm 6$ & $10 \pm 4$ & 14 \\
4IID20 & $6 \mathrm{HI}$ & $47 \pm 14$ & $14 \pm 2$ & $18 \pm 4$ & 27 \\
& $4 \mathrm{H}$ & $169 \pm 13$ & $120 \pm 11$ & $210 \pm 24$ & 166 \\
& $3 \mathrm{H} 5$ & $188 \pm 39$ & $219 \pm 56$ & $204 \pm 37$ & 204 \\
Control & 2 & $4 \pm 2$ & $3 \pm 1$ & $2 \pm 0.5$ & 3 \\
250GI2 & 3 & $146 \pm 29$ & $90 \pm 11$ & $43 \pm 4$ & 93 \\
FRA3B & $7 \mathrm{H}$ & $45 \pm 11$ & $26 \pm 6$ & $45 \pm 9$ & 38 \\
43IE5 & $\mathrm{IIM}$ & $138 \pm 38$ & $80 \pm 14$ & $54 \pm 6$ & $9 \mathrm{I}$ \\
& $4 \mathrm{M}$ & $245 \pm 107$ & $131 \pm 85$ & $128 \pm 42$ & 168 \\
& $8 \mathrm{~L}$ & $42 \mathrm{I} \pm 240$ & $216 \pm 66$ & $312 \pm 92$ & 316 \\
FRA3B & $24 \mathrm{H} 3$ & $73 \pm 3$ & $44 \pm 18$ & $65 \pm 21$ & $6 \mathrm{I}$ \\
530G4 & $\mathrm{IH}$ & $90 \pm 32$ & $141 \pm 40$ & $87 \pm 29$ & 106 \\
\hline
\end{tabular}

$431 \mathrm{E} 5$ cell clone $11 \mathrm{M}$ and the control BAC 250G12 cell clone 3 contain different copy numbers of the three markers (Table 3). Sequence from marker No. 1 was over-represented in both of these clones, indicating that the BACs either did not integrate or did not amplify as a unit. Importantly, all of the FRA3B BAC cell clones have a similar overall copy number as the control BAC cell clones, with the exception of clone 8L, which contained over 300 copies of the FRA3B BAC 431E5.

The frequency of gaps and breaks at integrated FRA3B BACs was not statistically different $(P$ value range $0.49-1$ ) between clones with different copy numbers. However, analysis of the BAC copy numbers revealed a trend whereby the fragility of an integrated FRA3B BAC increased with copy number. This trend was seen between the FRA3B BAC 431E5 cell clones 7H, 4M, and 8L and between the FRA3B BAC 530G4 cell clones 24H3 and $1 \mathrm{H}$ (Fig. 3). This suggests that both sequence content and copy number contribute to the fragility of these integrated BACs.

\section{Reduction of BAC Copy Number Reduces but Does Not Eliminate Fragility}

To address the possibility that the observed instability at the integration sites could be entirely due to the copy number of the integrated BACs and not sequence content, we reduced the copy number of the integrated BACs in five cell clones. To achieve this, we took advantage of the LoxP sites flanking the genomic inserts in the BACs. Cell clones containing multiple copies of the inte- 
TABLE 4. Copy number for All PCR Markers in the Reduced Clones

\begin{tabular}{lccccc}
\hline BAC & Clone & PCR I & PCR 2 & PCR 3 & Avg \\
\hline $\begin{array}{l}\text { Control } \\
\text { 4I2D20 }\end{array}$ & $6 \mathrm{HI}$ & $3 \pm 2$ & $3 \pm 1$ & $14 \pm 4$ & 6 \\
Control & 3 & $\mathrm{I} \pm 0.4$ & $2 \pm 1$ & $2 \pm 1$ & 2 \\
250GI2 & & & & & \\
FRA3B & IIM & $3 \pm 1$ & $2 \pm 0.3$ & $4 \pm 0.4$ & 3 \\
43IE5 & $4 \mathrm{M}$ & $6 \pm 3$ & $3 \pm 0.9$ & $3 \pm 0.7$ & 4 \\
FRA3B & IH & $2 \pm 0.3$ & $2 \pm 0.4$ & $2 \pm 0.5$ & 2 \\
530G4 & & & & & \\
\hline
\end{tabular}

grated BACs were treated with a retrovirus expressing Cre recombinase to induce deletion of intervening human genomic sequences. These cells were then sub-cloned and the resulting clones were analyzed using Q-PCR on genomic DNA as earlier. Using this method, we were able to clone and identify one reduced cell clone derived from both the control BAC 412D20 cell clone $6 \mathrm{H} 1$ and the control BAC 250G12 cell clone 3. Two reduced cell clones derived from the FRA3B BAC 431E5 cell clones $11 \mathrm{M}$ and $4 \mathrm{M}$ and one reduced cell clone derived from the FRA3B BAC 530G4 clone $1 \mathrm{H}$ were also identified. The BAC copy numbers in the reduced control BAC clones were reduced from 27 and 93 copies to six and two copies, respectively (Table 4). The reduced FRA3B BAC cell clones were reduced from 91 and 168 to three and four copies respectively, and finally, the reduced clone derived from the FRA3B BAC $530 \mathrm{G} 4$ clone $1 \mathrm{H}$ was reduced from 106 to two copies (Table 4). With the exception of PCR marker No. 3 in the reduced control BAC 412D20 clone $6 \mathrm{H} 1$, all the three PCR markers used to determine copy number were present in approximately equal amounts in the reduced cell clones, suggesting that in the reduced clones the BACs are present as whole units.

We analyzed 75 metaphases from these reduced clones for gaps and breaks at the site of BAC integration by FISH. All data were normalized with respect to total gaps and breaks per metaphase. In the absence of APH, no reduced clone showed any gaps or breaks at the BAC integration site (Fig. 5a). When treated with $0.4 \mu \mathrm{M}$ APH, all three reduced FRA3B BAC clones showed a somewhat lower frequency of gaps and breaks as compared to the unreduced clones, but still contained a significantly increased frequency of gaps and breaks when compared with the treated reduced control clones $(P$ value range 0.0003-0.024) (Fig. 5b). When treated with $0.4 \mu \mathrm{M} \mathrm{APH}$, none of the reduced control cell
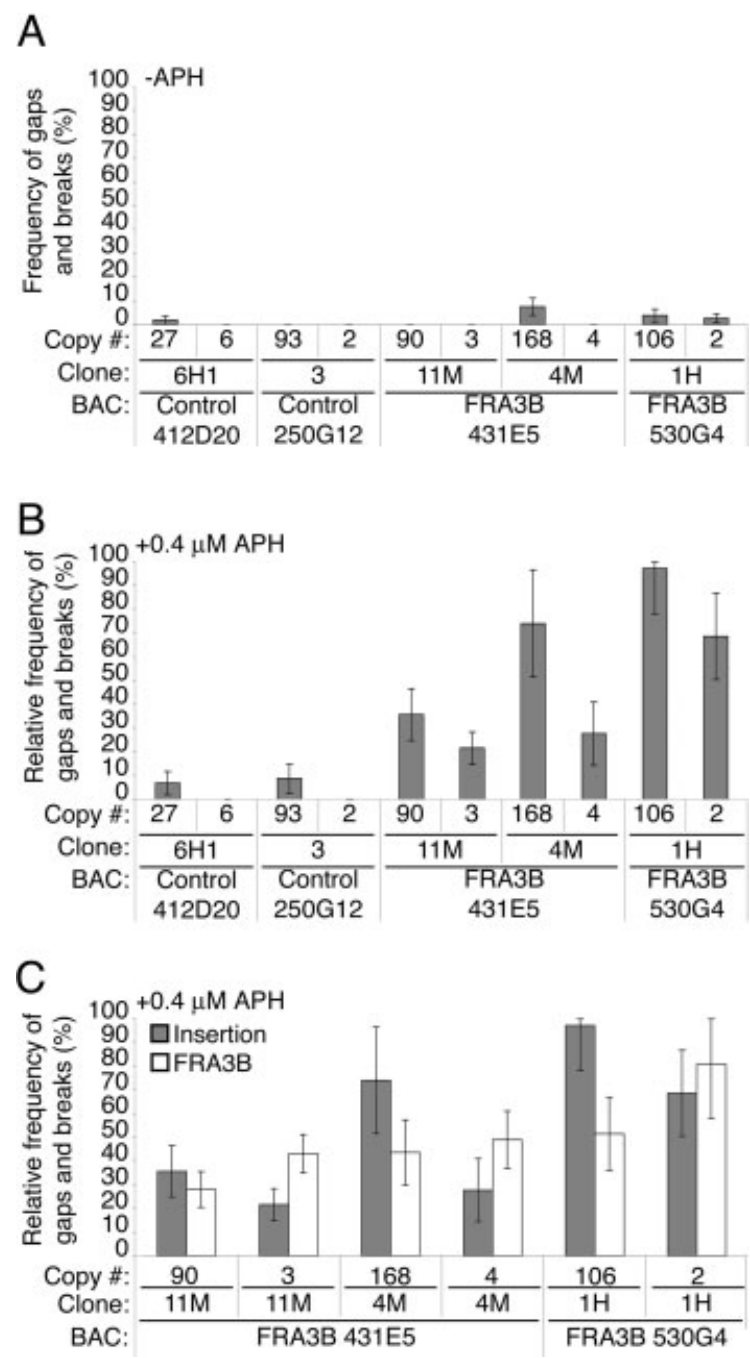

Figure 5. Cells containing FRA3B BAC integrations with reduced copy numbers show elevated gaps and breaks at the integration site when treated with $0.4 \mu \mathrm{m} \mathrm{APH}$. All APH treated samples were normalized relative to total gaps and breaks. The copy number for each clone is indicated. (A) Percent of integration sites broken as seen in fifty untreated metaphases for each clone. (B) The relative percentage of gaps and breaks at the site of integration after treatment with $0.4 \mu \mathrm{m}$ $\mathrm{APH}$ as found in both the original clones containing multiple BAC copy numbers and the reduced clones. (C) Relative percentage of gaps and breaks at both the integration site and the endogenous FRA3B locus for each reduced clone.

clones showed any gaps or breaks at the site of integration suggesting that the small number of breaks seen in the original clones are most likely a result of copy number (Fig. 5b). In addition, the reduced cell clones containing integrated FRA3B BACs showed a similar level of breakage at the integration site when compared with the endogenous FRA3B loci following $0.4 \mu \mathrm{M}$ APH treatment (Fig. 5c). These results demonstrate that even at a few copies, the sequence contained in the two FRA3B BACs was able to confer fragile site-like instability to the ectopic site of integration. 


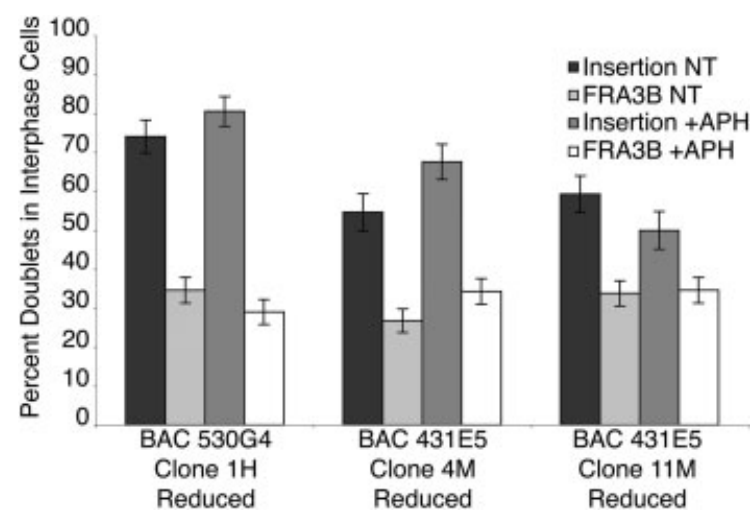

Figure 6. The percent of interphase FISH signals seen as doublets for both the integrated BAC and the two endogenous FRA3B loci in cells containing BAC insertions with reduced copy numbers. 108 interphase cells were scored for each clone and treatment.

\section{Integrated FRA3B BACs Replicate Earlier than Endogenous FRA3B Loci}

Late replication has been demonstrated for a number of CFSs and is believed to be a causal factor in their fragility (Le Beau et al., 1998; Wang et al., 1999; Focarelli et al., 2006). To determine if our integrated FRA3B BACs replicate at the same time as the endogenous FRA3B loci, we examined by FISH analysis 108 interphase cells from all three cell clones containing reduced FRA3B BAC insertions. The endogenous FRA3B site was found to have similar replication timing in all three of the reduced clones with doublet signals, indicative of completed replication, observed at $27-35 \%$ of the loci scored (Fig. 6). This frequency of replicated loci is consistent with the previously reported late replication timing of FRA3B (Le Beau et al., 1998). In contrast, the integrated FRA3B BAC sequences showed a significantly higher $(P<$ $0.0001)$ percentage of doublet signals across all three cell clones (Fig. 6). The reduced FRA3B BAC $431 \mathrm{E} 5$ cell clones $4 \mathrm{M}$ and $11 \mathrm{M}$ showed doublet signals at $55 \%$ and $59 \%$ of their integration sites, respectively. The reduced BAC 530G4 cell clone $1 \mathrm{H}$ had doublet signals at $74 \%$ of its integration sites, approximately a two to threefold increase in the number of signals that are replicated over the endogenous FRA3B. These data show that the integrated BAC sequences are completing replication much earlier than the endogenous FRA3B loci, yet still show the fragile site-like instability.

\section{DISCUSSION}

We have shown that in human cells sequences from two adjacent FRA3B BACs can transfer CFS- like instability to new loci in the genome. These data show that sequences taken from different regions of the FRA3B CFS are inherently unstable and that these sequences alone are sufficient to recapitulate much of the instability seen at CFSs. Because all of the FRA3B BAC integration sites were at unique chromosomal loci and retained similar levels of CFS-like instability, the genomic location of the BAC integrations does not appear to be a significant factor in the these experiments.

Although not statistically significant, cell clones containing integrated FRA3B BACs followed a trend whereby the greater the BAC copy number the greater the frequency of metaphases with gaps and breaks at the sites of integration. This was seen when comparing the fragility of the original FRA3B BAC cell clones that contained multiple BAC copies to each other (Fig. 3b), when original and reduced cell clones were compared to each other (Fig. 5b), or when any of the FRA3B BAC cell clones was compared to the endogenous FRA3B loci in the same cell clone (Figs. $3 \mathrm{c}$ and $5 \mathrm{c}$ ).

Gaps and breaks at CFSs have been shown to lead to the BFBC and intrachromosomal gene amplification events in Chinese hamster ovary cells and in cancer cells (Kuo et al., 1994; Coquelle et al., 1997, 2002). We found that the transfer of fragile site sequence is sufficient to recapitulate some of the amplification events that have been seen at endogenous CFS loci in other studies. Clones containing ectopic FRA3B BAC integrations displayed a statistically greater overall number of chromosomal rearrangements and a greater number of rearrangements indicative of BFBC than the control BAC integrations. These chromosomal rearrangements were not found in any of the cell clones that were reduced in copy number, suggesting that the copy number of BAC integrations is important in the formation of these rearrangements. However, the statistically significant difference in the number and type of rearrangements between FRA3B and control BAC integrations indicates that the sequence content of the FRA3B BACs also contributes to these rearrangements.

The search for a discrete sequence motif that is responsible for CFS fragility has historically been complicated by the large size of the CFS regions. Although we reduced the amount of sequence that we needed to interrogate, from $\sim 1 \mathrm{Mb}$ to just over $100 \mathrm{~kb}$, we were not able to precisely identify a sequence motif responsible for CFS fragility. In addition to the AT-rich flexibility peaks (Mishmar et al., 1998), recent work in a yeast model system 
has shown that short $(\mathrm{AT})_{5-34}$ perfect repeats within CFSs are hot spots for chromosome breakage and that the longer of these repeats $(\mathrm{AT})_{23-34}$ lead to stalled replication in 2D-gel analysis (Zhang and Freudenreich, 2007). It has also been hypothesized that the other sequence motifs capable of forming a strong secondary structures or stalling replication could be causal in the formation of gaps and breaks at CFSs (Durkin and Glover, 2007; Mirkin and Mirkin, 2007; Zhang and Freudenreich, 2007). Because both the control and the FRA3B BACs contain similar AT content, repetitive element content, tandem repeats, and palindrome motifs, it is unlikely that the presence of these features alone are responsible for the differences in the instability observed at the ectopic integrations. In addition, inverted repeats are present in control BAC 412D20 at a frequency that is approximately four times that of the FRA3B BACs suggesting that this motif is not sufficient to recapitulate CFS-like instability at an ectopic location. Both AT perfect repeats greater than or equal to $(\mathrm{AT})_{5}$ and flexibility peaks are present at the same frequency in the control BAC 250G12 as in both of the FRA3B BACs suggesting that presence of these motifs alone is also not responsible for the fragility of these ectopic FRA3B BAC integrations. However, it should be noted that although the frequency of greater than five perfect AT repeats was similar, the longest perfect AT repeat found in the control BACs was an $(\mathrm{AT})_{19}$ repeat, whereas the longest motif in the FRA3B BACs was an $(\mathrm{AT})_{24}$ repeat found in the overlapping region of the two FRA3B BACs. Given that, it has been found that AT perfect repeats $(\mathrm{AT})_{21-34}$ units in size were found to stall replication forks better (Zhang and Freudenreich, 2007) and to form stronger cruciform structures in yeast (Dayn et al., 1991) than do sequences with a lower number of repeats, there may be some threshold effect whereby an $(\text { AT })_{19}$ repeat is not sufficient to contribute to fragility whereas an $(\mathrm{AT})_{24}$ repeat is. An examination of the human genome reveals that there are thousands of perfect $(\mathrm{AT})_{24}$ repeats, many of which are not associated with CFSs. Two of these sites, located at 9 q21 and $15 q 25$, were examined using the TwistFlex program. Like the $(\mathrm{AT})_{24}$ repeat found in our FRA3B BACs, these repeats were also found to be located in the flexibility peaks and surrounded by regions of high AT content $(>60 \%)$. Because these repeats were found in nonfragile regions of the genome, and were indistinguishable from the $(\mathrm{AT})_{24}$ repeat found in our FRA3B BACs in size or sequence context, it is suggested that although a single $(\mathrm{AT})_{24}$ may be contributory to the fragility of CFSs, the contribution of sequence to the instability of our BAC integrations, and to CFSs in general, is likely to be more complex.

Although a number of studies have reported that molecularly characterized CFS are highly flexible and AT rich (Boldog et al., 1997; Mishmar et al., 1998; Ried et al., 2000; Shiraishi et al., 2001; Arlt et al., 2002; Limongi et al., 2003; Ferber et al., 2004), a few studies differ in their findings. Helmrich et al., examined sequences from 15 human and eight mouse CFSs and found no increase in DNA flexibility when compared with the controls (Helmrich et al., 2006). Similarly, Tsantoulis et al., describes CFSs as being flexibility peak poor and GC rich (Tsantoulis et al., 2008). Both of these studies included large regions of sequence flanking the CFSs in their analyses, as opposed to a few hundred kilobases of most fragile DNA at the center of molecularly characterized CFSs as in most other studies of CFS sequence. In addition, Tsantoulis et al. included CFSs that have only been mapped at the resolution of a chromosome band in their analysis. These disparities likely account for the differences in findings and interpretations.

A few studies have explored the contribution of sequence to CFS instability by examining chromosome breakage at endogenous CFSs that contain large deletions. Hamster human chromosome 3hybrid cell clones containing large deletions of FRA3B derived during tumorigenesis were found to have no significant reduction in fragility (Corbin et al., 2002). More recently, a significant reduction in the fragility of FRA3B was reported in seven clones with large (several hundred kilobases) APHinduced deletions centered within the fragile site (Durkin et al., 2008). Many of these deletions encompass the sequences contained in our FRA3B BACs. Finally, a tumor cell line containing a deletion of the entire FRAXB locus was found to have completely lost fragility of FRAXB (Arlt et al., 2002). These findings suggest that many sequence motifs spread throughout the region are likely to contribute to the fragility of CFSs and are in agreement with our results that the two adjoining regions of FRA3B were capable of recapitulating CFS-like instability at ectopic sites. Furthermore, these findings imply that whatever features are necessary for CFS fragility are located within the defined CFS sequence boundaries and cannot be eliminated without a complete deletion of the site.

To examine other factors that could contribute to CFS fragility, we analyzed the integrated BACs in our reduced clones for replication timing. It was 
found that ectopic FRA3B BAC integrations were 2-3 times more likely than the endogenous FRA3B sites to be replicated. Despite earlier replication timing, these sites were still unstable and formed gaps and breaks under conditions of replication stress. These findings suggest that ectopic FRA3B BAC integrations do not need to be as late replicating as the endogenous loci to be unstable. Because these findings were determined using a FISH assay with the entire FRA3B BACs as probes, we cannot exclude the possibility that smaller regions within the integrated BACs are late replicating. However these data suggest that late replication is not necessary for the formation of gaps and breaks at our FRA3B ectopic integrations.

Our findings show that sequence alone is a critical factor underlying the instability seen at CFSs, and may help to elucidate further mechanisms involved in CFS instability. While it has long been hypothesized that specific sequences are causal to the fragility of CFSs, this is the first example showing that CFS instability can be transferred to ectopic sites in mammalian cells by more than one region and that this instability can be seen with as little as $300 \mathrm{~kb}$ of transferred sequence. These findings are central to understanding the fundamental mechanisms underlying CFS instability, the role of CFSs in the normal functioning of human cells, and in early breakage events in tumorigenesis.

\section{ACKNOWLEDGMENTS}

We thank Matthew Butler for his assistance and advice in critically reading the manuscript. We thank Matthew Glover for technical assistance.

\section{REFERENCES}

Arlt MF, Miller DE, Beer DG, Glover TW. 2002. Molecular characterization of FRAXB and comparative common fragile site instability in cancer cells. Genes Chromosomes Cancer 33:82-92.

Arlt MF, Xu B, Durkin SG, Casper AM, Kastan MB, Glover TW. 2004. BRCA1 is required for common-fragile-site stability via its G2/M checkpoint function. Mol Cell Biol 24:6701-6709.

Bartkova J, Horejsi Z, Koed K, Kramer A, Tort F, Zieger K, Guldberg P, Sehested M, Nesland JM, Lukas C, Orntoft T, Lukas J, Bartek J. 2005. DNA damage response as a candidate anti-cancer barrier in early human tumorigenesis. Nature 434:864-870.

Bednarek AK, Keck-Waggoner CL, Daniel RL, Laflin KJ, Bergsagel PL, Kiguchi K, Brenner AJ, Aldaz CM. 2001. WWOX, the FRA16D gene, behaves as a suppressor of tumor growth. Cancer Res 61:8068-8073.

Benson G. 1999. Tandem repeats finder: A program to analyze DNA sequences. Nucleic Acids Res 27:573-580.

Boldog F, Gemmill RM, West J, Robinson M, Robinson L, Li E, Roche J, Todd S, Waggoner B, Lundstrom R, Jacobson J, Mullokandov MR, Klinger H, Drabkin HA. 1997. Chromosome 3p14 homozygous deletions and sequence analysis of FRA3B. Hum Mol Genet 6:193-203.
Boldog FL, Waggoner B, Glover TW, Chumakov I, Le Paslier D, Cohen D, Gemmill RM, Drabkin HA. 1994. Integrated YAC contig containing the 3 p 14.2 hereditary renal carcinoma $3 ; 8$ translocation breakpoint and the fragile site FRA3B. Genes Chromosomes Cancer 11:216-221.

Casper AM, Nghiem P, Arlt MF, Glover TW. 2002. ATR regulates fragile site stability. Cell 111:779-789.

Coquelle A, Pipiras E, Toledo F, Buttin G, Debatisse M. 1997. Expression of fragile sites triggers intrachromosomal mammalian gene amplification and sets boundaries to early amplicons. Cell 89:215-225.

Coquelle A, Rozier L, Dutrillaux B, Debatisse M. 2002. Induction of multiple double-strand breaks within an hsr by meganucleaseISceI expression or fragile site activation leads to formation of double minutes and other chromosomal rearrangements. Oncogene 21:7671-7679.

Corbin S, Neilly ME, Espinosa R, III, Davis EM, McKeithan TW, Le Beau MM. 2002. Identification of unstable sequences within the common fragile site at 3p14.2: Implications for the mechanism of deletions within fragile histidine triad gene/common fragile site at 3p14.2 in tumors. Cancer Res 62:3477-3484.

Dayn A, Malkhosyan S, Duzhy D, Lyamichev V, Panchenko Y, Mirkin S. 1991. Formation of (dA-dT)n cruciforms in Escherichia coli cells under different environmental conditions. J Bacteriol 173: 2658-2664.

Dunham MJ, Badrane H, Ferea T, Adams J, Brown PO, Rosenzweig F, Botstein D. 2002. Characteristic genome rearrangements in experimental evolution of Saccharomyces cerevisiae. Proc Natl Acad Sci USA 99:16144-16149.

Durkin SG, Glover TW. 2007. Chromosome fragile sites. Annu Rev Genet 41:169-192.

Durkin SG, Arlt MF, Howlett NG, Glover TW. 2006. Depletion of CHK1, but not CHK2, induces chromosomal instability and breaks at common fragile sites. Oncogene 25:4381-4388.

Durkin SG, Ragland RL, Arlt MF, Mulle JG, Warren ST, Glover TW. 2008. Replication stress induces tumor-like microdeletions in FHIT/FRA3B. Proc Natl Acad Sci USA 105:246-251.

Elder FF, Robinson TJ. 1989. Rodent common fragile sites: Are they conserved? Evidence from mouse and rat. Chromosoma 97:459-464.

Ferber MJ, Eilers P, Schuuring E, Fenton JA, Fleuren GJ, Kenter G, Szuhai K, Smith DI, Raap AK, Brink AA. 2004. Positioning of cervical carcinoma and Burkitt lymphoma translocation breakpoints with respect to the human papillomavirus integration cluster in FRA8C at 8q24.13. Cancer Genet Cytogenet 154:1-9.

Finnis M, Dayan S, Hobson L, Chenevix-Trench G, Friend K, Ried K, Venter D, Woollatt E, Baker E, Richards RI. 2005. Common chromosomal fragile site FRA16D mutation in cancer cells. Hum Mol Genet 14:1341-1349.

Focarelli ML, Montagna C, Colombo R, Ried T, Vezzoni P, Musio A. 2006. SMC1 inhibition results in FRA3B expression but has no effect on its delayed replication. Mutat Res 595:23-28.

Glover TW, Stein CK. 1987. Induction of sister chromatid exchanges at common fragile sites. Am J Hum Genet 41:882-890.

Glover TW, Stein CK. 1988. Chromosome breakage and recombination at fragile sites. Am J Hum Genet 43:265-273.

Glover TW, Hoge AW, Miller DE, Ascara-Wilke JE, Adam AN, Dagenais SL, Wilke CM, Dierick HA, Beer DG. 1998. The murine Fhit gene is highly similar to its human orthologue and maps to a common fragile site region. Cancer Res 58:3409-3414.

Gorgoulis VG, Vassiliou LV, Karakaidos P, Zacharatos P, Kotsinas A, Liloglou T, Venere M, Ditullio RA, Jr. Kastrinakis NG, Levy B, Kletsas D, Yoneta A, Herlyn M, Kittas C, Halazonetis TD. 2005. Activation of the DNA damage checkpoint and genomic instability in human precancerous lesions. Nature 434:907-913.

Hellman A, Rahat A, Scherer SW, Darvasi A, Tsui LC, Kerem B. 2000. Replication delay along FRA7H, a common fragile site on human chromosome 7, leads to chromosomal instability. Mol Cell Biol 20:4420-4427.

Helmrich A, Stout-Weider K, Hermann K, Schrock E, Heiden T. 2006. Common fragile sites are conserved features of human and mouse chromosomes and relate to large active genes. Genome Res 16:1222-1230.

Howlett NG, Taniguchi T, Durkin SG, D'Andrea AD, Glover TW. 2005. The Fanconi anemia pathway is required for the DNA replication stress response and for the regulation of common fragile site stability. Hum Mol Genet 14:693-701.

Huebner K, Croce CM. 2003. Cancer and the FRA3B/FHIT fragile locus: It's a HIT. Br J Cancer 88:1501-1506. 
Kim SY, Horrigan SK, Altenhofen JL, Arbieva ZH, Hoffman R, Westbrook CA. 1998. Modification of bacterial artificial chromosome clones using Cre recombinase: Introduction of selectable markers for expression in eukaryotic cells. Genome Res 8:404412.

Kuo MT, Vyas RC, Jiang LX, Hittelman WN. 1994. Chromosome breakage at a major fragile site associated with P-glycoprotein gene amplification in multidrug-resistant CHO cells. Mol Cell Biol 14:5202-5211.

Le Beau MM, Rassool FV, Neilly ME, Espinosa R, III, Glover TW, Smith DI, McKeithan TW. 1998. Replication of a common fragile site, FRA3B, occurs late in $S$ phase and is delayed further upon induction: Implications for the mechanism of fragile site induction. Hum Mol Genet 7:755-761.

Lemoine FJ, Degtyareva NP, Lobachev K, Petes TD. 2005. Chromosomal translocations in yeast induced by low levels of DNA polymerase a model for chromosome fragile sites. Cell 120:587598.

Limongi MZ, Pelliccia F, Rocchi A. 2003. Characterization of the human common fragile site FRA2G. Genomics 81:93-97.

Livak KJ, Schmittgen TD. 2001. Analysis of relative gene expression data using real-time quantitative PCR and the 2(-Delta Delta $\mathrm{C}(\mathrm{T}))$ method. Methods 25:402-408.

McAllister BF, Greenbaum IF. 1997. How common are common fragile sites: Variation of aphidicolin-induced chromosomal fragile sites in a population of the deer mouse (Peromyscus maniculatus). Hum Genet 100:182-188

Michael D, Beer DG, Wilke CW, Miller DE, Glover TW. 1997. Frequent deletions of FHIT and FRA3B in Barrett's metaplasia and esophageal adenocarcinomas. Oncogene 15:1653-1659.

Mirkin EV, Mirkin SM. 2007. Replication fork stalling at natural impediments. Microbiol Mol Biol Rev 71:13-35.

Mishmar D, Rahat A, Scherer SW, Nyakatura G, Hinzmann B, Kohwi Y, Mandel-Gutfroind Y, Lee JR, Drescher B, Sas DE, Margalit H, Platzer M, Weiss A, Tsui LC, Rosenthal A, Kerem B. 1998. Molecular characterization of a common fragile site (FRA7H) on human chromosome 7 by the cloning of a simian virus 40 integration site. Proc Natl Acad Sci USA 95:8141-8146.

Musio A, Montagna C, Mariani T, Tilenni M, Focarelli ML, Brait L, Indino E, Benedetti PA, Chessa L, Albertini A, Ried T, Vezzoni P. 2005. SMC1 involvement in fragile site expression. Hum Mol Genet 14:525-533

Ohta M, Inoue H, Cotticelli MG, Kastury K, Baffa R, Palazzo J, Siprashvili Z, Mori M, McCue P, Druck T, Croce CM, Huebner K. 1996. The FHIT gene, spanning the chromosome 3p14.2 fragile site and renal carcinoma-associated $\mathrm{t}(3 ; 8)$ breakpoint, is abnormal in digestive tract cancers. Cell 84:587-597.

Palakodeti A, Han Y, Jiang Y, Le Beau MM. 2004. The role of late/ slow replication of the FRA16D in common fragile site induction. Genes Chromosomes Cancer 39:71-76.

Rassool FV, McKeithan TW, Neilly ME, van Melle E, Espinosa R, III, Le Beau MM. 1991. Preferential integration of marker DNA into the chromosomal fragile site at 3p14: An approach to cloning fragile sites. Proc Natl Acad Sci USA 88:6657-6661.

Ried K, Finnis M, Hobson L, Mangelsdorf M, Dayan S, Nancarrow JK, Woollatt E, Kremmidiotis G, Gardner A, Venter D, Baker E, Richards RI. 2000. Common chromosomal fragile site FRA16D sequence: Identification of the FOR gene spanning FRA16D and homozygous deletions and translocation breakpoints in cancer cells. Hum Mol Genet 9:1651-1663.

Roeder GS, Fink GR. 1980. DNA rearrangements associated with a transposable element in yeast. Cell 21:239-249.

Rozier L, El-Achkar E, Apiou F, Debatisse M. 2004. Characterization of a conserved aphidicolin-sensitive common fragile site at human 4q22 and mouse 6C1: Possible association with an inherited disease and cancer. Oncogene 23:6872-6880.

Ruiz-Herrera A, Garcia F, Fronicke L, Ponsa M, Egozcue J, Caldes MG, Stanyon R. 2004. Conservation of aphidicolin-induced fragile sites in Papionini (Primates) species and humans. Chromosome Res 12:683-690.

Schwartz M, Zlotorynski E, Goldberg M, Ozeri E, Rahat A, le Sage C, Chen BP, Chen DJ, Agami R, Kerem B. 2005. Homologous recombination and nonhomologous end-joining repair pathways regulate fragile site stability. Genes Dev 19:2715-2726.

Shiraishi T, Druck T, Mimori K, Flomenberg J, Berk L, Alder H, Miller W, Huebner K, Croce CM. 2001. Sequence conservation at human and mouse orthologous common fragile regions, FRA3B/ FHIT and Fra14A2/Fhit. Proc Natl Acad Sci USA 98:5722-5727.

Smeets DF, van de Klundert FA. 1990. Common fragile sites in man and three closely related primate species. Cytogenet Cell Genet 53:8-14.

Soulie J, De Grouchy J. 1981. A cytogenetic survey of 110 baboons (Papio cynocephalus). Am J Phys Anthropol 56:107-113.

Stone DM, Jacky PB, Hancock DD, Prieur DJ. 1991. Chromosomal fragile site expression in dogs: I. Breed specific differences. Am J Med Genet 40:214-222.

Sutherland GR. 2003. Rare fragile sites. Cytogenet Genome Res 100:77-84.

Tsantoulis PK, Kotsinas A, Sfikakis PP, Evangelou K, Sideridou M, Levy B, Mo L, Kittas C, Wu XR, Papavassiliou AG, Gorgoulis VG. 2008. Oncogene-induced replication stress preferentially targets common fragile sites in preneoplastic lesions. A genomewide study. Oncogene 27:3256-3264.

Wang L, Darling J, Zhang JS, Huang H, Liu W, Smith DI. 1999. Allele-specific late replication and fragility of the most active common fragile site, FRA3B. Hum Mol Genet 8:431-437.

Wang ND, Testa JR, Smith DI. 1993. Determination of the specificity of aphidicolin-induced breakage of the human 3 p 14.2 fragile site. Genomics 17:341-347.

Wang Z, Engler P, Longacre A, Storb U. 2001. An efficient method for high-fidelity BAC/PAC retrofitting with a selectable marker for mammalian cell transfection. Genome Res 11:137-142.

Warburton PE, Giordano J, Cheung F, Gelfand Y, Benson G. 2004. Inverted repeat structure of the human genome: The X-chromosome contains a preponderance of large, highly homologous inverted repeats that contain testes genes. Genome Res 14:18611869.

Wilke CM, Guo SW, Hall BK, Boldog F, Gemmill RM, Chandrasekharappa SC, Barcroft CL, Drabkin HA, Glover TW. 1994. Multicolor FISH mapping of YAC clones in 3 p14 and identification of a YAC spanning both FRA3B and the $\mathrm{t}(3 ; 8)$ associated with hereditary renal cell carcinoma. Genomics 22:319-326.

Wilke CM, Hall BK, Hoge A, Paradee W, Smith DI, Glover TW. 1996. FRA3B extends over a broad region and contains a spontaneous HPV16 integration site: Direct evidence for the coincidence of viral integration sites and fragile sites. Hum Mol Genet 5:187-195.

Wilson K. 2001. Preparation of genomic DNA from bacteria. Curr Protoc Mol Biol Chapter 2:Unit 2.4.

Zhang H, Freudenreich CH. 2007. An AT-rich sequence in human common fragile site FRA16D causes fork stalling and chromosome breakage in S. cerevisiae. Mol Cell 27:367-379.

Zhu M, Weiss RS. 2007. Increased common fragile site expression, cell proliferation defects, and apoptosis following conditional inactivation of mouse Hus1 in primary cultured cells. Mol Biol Cell 18:1044-1055. 